ELORE (ISSN 1456-3010), vol. $14-1 / 2007$.

Julkaisija: Suomen Kansantietouden Tutkijain Seura ry. [http://www.elore.fi/arkisto/1_07/paa1_07.pdf]

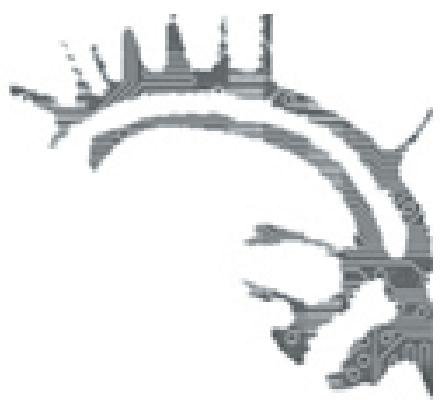

\title{
HORKKA JA USKOMUSTARINAT
}

\section{$\underline{\text { Piret Paal }}$}

Tutkimuksia vanhasta kertomusperinteestä eli 1800-luvulla ja viime vuosisadan alkuvaiheessa kerätystä aineistosta ilmestyy nykyään harvoin. Runsaaseen arkistoaineistoon perustuva analyysi tarjoaa kuitenkin hyvät lähtökohdat myös nykyaikaisen kertomusperinteen ymmärtämiseen. Tarinoilla on oma tärkeä tehtävänsä ajassa: ne selittävät ja muokkaavat todellisuutta mukautuen samalla itse uudenlaisiin yhteiskunnan realiteetteihin. Tässä artikkelissa tarkastelen horkkaan eli malariaan liittyvää suomalaista tarinaperinnettä. Horkkatarinoissa kuvataan, kuinka horkka personoituna tautiolentona pyrkii ihmisen sisään vavisuttamaan tätä ja kuinka horkasta hankkiudutaan eroon. Johdantona aiheeseen käsittelen horkkatutkimuksen historiaa Suomessa ja esittelen lähdeaineistoa. Pohdin horkan asemaa suomalaisessa uskomusperinteessä, kuvailen horkkaan liittyviä uskomuksia ja horkkatarinoissa esiintyviä motiiveja. Käsittelen kertomusperinteen ja todellisuuden välistä suhdetta horkkakertomuksien valossa ja kysyn, mikä oli näiden kertomusten mahdollinen funktio ennen kuin sairauden taantuminen teki niistä pelkkää viihdettä. Horkan parantamisesta kertovat tekstit ja siihen liittyvät uskomukset, kuten myös horkan parantamiseen liittyvän loitsuperinteen, olen jättänyt tämän artikkelin ulkopuolelle.

Vaikka tarkastelen folkloristiikan kannalta traditionaalista kertomusperinnettä, tarinan tai kertomuksen käsitettä ei mielestäni voi määritellä tarkasti. Horkkakertomusten tyyli ja laatu vaihtelevat, mutta tarinoissa voi todeta olevan joitakin toistuvia motiiveja ja tietynlainen juoni eli skeema. Joskus tarinoissa esiintyvät henkilöt ovat tuttuja kyläläisiä, joskus taas kyseessä ovat stereotyyppiset roolihahmot, kuten talon isäntä, nuori tyttö tai renki. Myös tapahtumien aika ja paikka vaihtelevat. Tässä tarkastelemilleni kertomuksille on yhteistä se, että niissä käsitellään horkkaa ja että kyseessä on arkistoitu aineisto.

Artikkelini edustaa vertailevan tutkimuksen periaatteita, koska kulttuurien välisiä eroja ja samankaltaisuuksia voidaan selvittää vain maantieteellisesti tai historiallisesti läheisiä kulttuureja vertailemalla (Dundes 2002, 123). Tämän takia artikkelissani esiintyy runsaasti viittauksia juuri virolaiseen horkkaperinteeseen. Vaikka vertailevaa lähestymistapaa on monesti kritisoitu, se on arkistoaineiston käsittelyssä toimiva menetelmä. On totta, ettei kaikkia horkkaan liittyviä kertomuksia ole mahdollista 
kuvailla, koska arkistoaineisto on heterogeenistä. Stereotyyppisten motiivien lisäksi löytyy runsaasti uskomuksia, joista on vain yksi merkintä. Yksittäiset tiedot eivät välttämättä ole vähemmän merkittäviä, sillä arkistotekstien tallentaminen ei ole ollut järjestelmällistä. Tämä ei tarkoita sitä, etteikö arkistoaineisto soveltuisi tilastolliseen tutkimukseen, koska vastaajien määrä kytkeytyy usein paikallisen kerääjän aktiivisuuteen. On aika todennäköistä, että horkka-aiheisia kertomuksia on esiintynyt myös muualla Suomessa runsaammin mutta niitä ei ole tallennettu riittävästi. Siksi ei ole myöskään järkevää karsia tilastollisesti vähempiarvoisia tekstejä pois. Tutkijana on myönnettävä, että horkkaperinteen ymmärtämiseen olisi ehdottomasti tarvittu teemahaastatteluja. Koska horkkakertomukset edustavat kadonnutta suullista perinnettä, lopullista kuvaa niistä ei voida luoda. Samoihin lähteisiin on palattava aina uudestaan.

\section{HorkKatutkimuksen taustoja SuOmessa}

Horkan kansainvälisesti tunnettu nimitys malaria juontaa juurensa 1600-luvun Italiasta. Latinan malus aria ja italian mala aria merkitsevät 'pahaa ilmaa'. Tämä on viittaus uskomukseen, jonka mukaan "roomalaisen kuumeen" nostattaja oli soista leviävä "paha höyry" eli haiseva utu. Yhteys malarian ja vetisten alueiden välillä on ollut tunnettu jo kauan. Tartunnan leviäminen sääsken pistoksen kautta saatiin selville vasta 1900-luvulla (Senior Scribe Publications 2003). Taudin tuntomerkit ovat korkea kuume ja kylmänpudistukset. Säännöllisesti esiintyvien sairauskohtauksien välillä voi tartunnan saanut ihminen tuntea itsensä täysin terveeksi (Wyler 1990, 2061-2062). Suomessa esiintyi malariaa vielä jatkosodan aikana (Kaipainen 2005), vaikka laajemmat horkkaepidemiat taantuivat jo 1800-luvun puolivälissä (ks. esim. Kjærgaard 2000, 18-20). 1800-luvun ja 1900-luvun lääketieteessä tunnettiin jo kiniinin hoitava vaikutus horkkapotilaisiin, mutta lääke oli kallis ja horkan hoidossa olivat ensisijaisesti käytössä erilaiset kotikonstit (Paal 2002; 2004; 2006).

Suomessa pelkästään horkkaan liittyviä tutkimuksia ei ole tehty ollenkaan. Yhtenä syynä on ehkä ollut 1900-luvun alkupuolella vaikuttaneiden suomalaisten kansanperinteen tutkijoiden suuntautuminen suomalaiseen mytologiaan, satuihin, runoihin ja loitsuihin. Tarina-aineistot ovat nousseet tutkijoiden kiinnostuksen kohteeksi vasta myöhemmin. Kirjoituksia kansanlääkinnästä löytyy kyllä jo vuodelta 1782: Christian Lencqvistin De superstitione veterum Fennorum theoretica et practica, jossa sairauksia kuvaillaan ilkeiden ihmisten tai jumalan lähettämiksi. Ihmishahmoisia tauteja luonnehtivat töissään sekä Elias Lönnrot (ks. Lönnrot 1984, 191-192 [1832]) että Matti Varonen. Varonen kirjoittaa, että ruttotaudit ovat olentoja, jotka kulkevat ihmisten joukossa tehdäkseen heille pahaa (Varonen 1898, 17-18). Horkkaa hän ei kuitenkaan mainitse.

Horkka mainitaan ensimmäisen kerran Ilmari Mannisen tutkimuksessa Die dämonistischen Krankheiten in Finnischen Volksaberglauben (1922). Mannisen tutkimustyö perustuu hänen keräämiinsä lähdeaineistoihin vuodesta 1917 alkaen (ks. NaakkaKorhonen 1997, 69). Mannisen mukaan horkka (tai vilutauti) on tunnettu lähinnä Itä- 
Piret PaAL

Suomessa, mutta vastaavia kuvitelmia löytyy myös Länsi-Suomesta. Hänen mukaansa kyseessä olisi laina, joka on omaksuttu Itä-Suomessa Venäjän suunnalta ja lännessä taas germaaneilta (Manninen 1922, 146-149). Ilmari Mannisen päätelmät lainoista ovat vain suuntaa antavia ja edustavat hänen aikalaistensa tutkimusintressejä.

Lauri Simonsuuren julkaisemasta kirjasta Myytillisiä tarinoita (1947) kappaleesta "Taudit" löytyy neljä horkkatarinaa (Simonsuuri 1999, 445-446). Hänen toimittamassaan uskomustarinoiden tyyppiluettelossa Typen- und Motivverzeichnis der finnischen mytischen Sagen (1961; uudistettuna Jauhiainen 1999) on myös viite suomalaisiin horkkakertomuksiin. Samalta aikakaudelta on peräisin myös Lauri Hongon väitöskirja Krankheitsprojektile. Untersuchung über eine urtümliche Krankheitserklärung (1959), jossa Honko käsittelee kolmea projektiilisairautta: lentoa, pistosta ja ruttoa. Honko väittää Manniseen tukeutuen, että Länsi-Suomessa esiintyvän ihmishahmoisen ruton itäsuomalainen (Savo, Karjala) vastine on horkka (Honko 1959, 154). Krankheitsprojektille-teoksesta löytyvässä sairauksien luettelossa on horkan länsisuomalainen nimitys vilutauti saksaksi käännetty pelkästään vilustumistaudiksi (Erkältung) (Honko 1959, 128). Matti Hako on kirjannut suomalaista kansanlääkintää käsittelevään teokseensa Kansanomainen lääkintätietous (1975) yhdeksän horkan parantamiseen liittyvää tekstiä ja yhden uskomustarinan (Hako 2000, 56-58).

Malarian esiintymistä Suomessa lääkärin näkökulmasta on pohtinut Niilo Pesonen tutkimuksessaan Piirilääkärinä Suomessa 1800-luvulla (Pesonen 1990, 149-150). Suomen väestön tautihistoria on noussut tutkijoiden mielenkiinnon kohteeksi vasta 2000-luvulla, kun lääketieteen piirissä on huomattu, että ihmiskunnan tautien historia on merkittävästi vaikuttanut ihmisten ja yhteiskunnan kehitykseen. Horkasta ja sen esiintymisestä Suomessa ovat sen jälkeen kirjoittaneet monet suomalaiset tutkijat. Hyvänä lähdetiedostona mainittakoon tässä Heikki S. Vuorisen kirjat Tauti(n)en bistoria (2002) ja Tautinen Suomi 1857-1865 (2006). Myös Mika Kallioisen Rutto ja rukous (2005) käsittelee tartuntatauteja esiteollisen ajan Suomessa. On oleellista ottaa huomioon, että nämä viimeksi mainitut tutkimukset lähestyvät horkkaa lääkäreiden ja lääketieteen historian näkökulmasta, jossa lähdeaineistona ovat kirjalliset asiakirjat eikä suullinen perinne.

\section{SUOMALAISET HORKKA-AINESTOT}

Suomalaisen Kirjallisuuden Seuran kansanrunousarkistossa on tallennettuna noin 400 horkkakertomusta, joista suurin osa käsittelee horkan häätöä. Horkkatarinoita on kerätty 1930-luvulla käynnistyneissä tarinankeruissa, kuten Kalevalan riemuvuoden kilpakeruussa vuosina 1935-1936 sekä pienemmissä keruissa (KT, VK, TK, PK). Merkittävän henkilökohtaisen panoksen ovat antaneet kaksi kerääjää: Juho Hyvärinen ja Matti Moilanen. Heidän ansiostaan on arkistoon tallennettu erittäin runsaasti tietoa juuri Laatokan-Karjalan eli Raja-Karjalan seudun horkasta. Edellä mainittujen kilpakeruiden aikana horkkaperinne on ollut jo katoamassa. Tämän voi päätellä lyhykäisistä vastauksista: "Ne puhu ennem pal'io siitä viluta(u)vista, ni nüt 


\section{HORKKA JA USKOMUSTARINAT}

siit' ei puhuk kukkam mittää'. Ne iham pit tuommoesta kuumetta ennev vilutaotia." (SKS KRA Kuitunen, Oskar 1095a, 1927.) Laatokan-Karjalasta ja Raja-Karjalan alueelta on yhteensä kerätty 118 tarinaa ja uskomusta. Horkkaperinnettä on tallennettu runsaasti Itä-Suomesta, Hämeestä, Etelä- ja Pohjois-Savosta ja Karjalasta (ks. myös Manninen 1922, 146-149). Yksittäisiä tekstejä on kerätty myös Pohjois-Suomesta (Kainuu, Etelä- ja Pohjois-Pohjanmaa). Myös virolaisen horkkaperinteen levinneisyys on itä- ja eteläsuuntainen. Virolaista aineistoa oli käytössäni noin 600 tekstiä, joista noin kolmasosa on uskomustarinoita. Tässä artikkelissa käyttämäni aineistot ovat lähtöisin Viron kansanrunousarkiston (Eesti Rahvaluule Arhiiv) kokoelmista Eisen (E), Hurt $(\mathrm{H})$ ja ERA. Suurin osa virolaisesta horkka-aineistosta on kerätty vuosina 1920-1960, vaikka uskomustarinoita kerättiin säännöllisesti jo 1880-luvulta alkaen (ks. Paal 2004, 18-20).

\section{Taulukeko 1.}

Horkkatekstien määrä Suomessa alueittain SKS:n aineiston valossa.

\section{Suomalaiset maakunnat ja historialliset alueet}

$\begin{array}{lr}\text { Laatokan Karjala (Raja-Karjala) (i) } & 118 \\ \text { Etelä-Savo (f) } & 56 \\ \text { Pohjois-Karjala (j) } & 41 \\ \text { Etelä-Karjala (Karjalan kannas) (h) } & 21 \\ \text { Varsinais-Suomi (a) } & 20 \\ \text { Häme (d) } & 20 \\ \text { Pohjois-Savo (g) } & 16 \\ \text { Satakunta (b) } & 14 \\ \text { Etelä-Pohjanmaa (k) } & 6 \\ \text { Keski-Suomi (e) } & 5 \\ \text { Viron Inkeri (u) } & 4 \\ \text { Suomalaiset siirtolaisalueet Ruotsissa (oR) } & 2 \\ \text { Pohjois-Pohjanmaa (l) } & 1 \\ \text { Kainuu (m) } & 1\end{array}$




\section{Piret Paal}

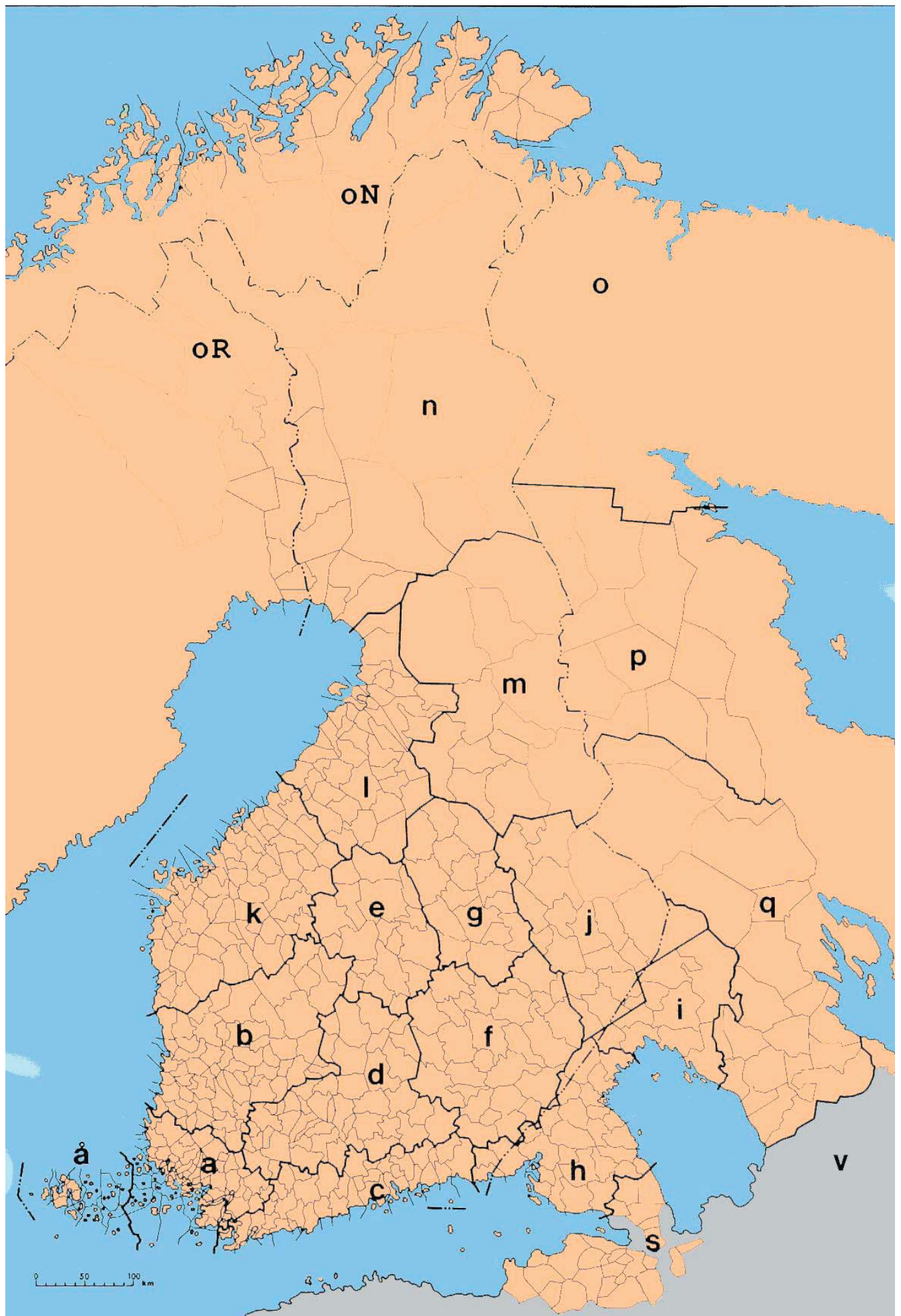

Suomen-Karjalan historiallinen kulttuurialue. 


\section{HORKKA JA USKOMUSTARINAT}

\section{HORKKA ILMESTYY}

Suomalaisissa tarinoissa horkka kuvataan tavallisesti miespuoliseksi henkilöksi. Miehinä esiintyvät Suomessa myös ihmishahmoinen piru (Klemettinen 1997, 83-84) sekä rutto (Honko 1959, 154). Tämä poikkeaa virolaisesta horkkaperinteestä, jossa horkka (mutta myös muut demoniset hahmot) esiintyy sekä nais- että mieshahmoisena (Paal 2004, 52-54). Horkka voi tarpeen tullen käyttää naisen ääntä myös Suomessa. Horkkatarinoille on tyypillistä, että horkka houkuttelee piiloutunutta uhriaan ulos piilopaikastaan, tuttua (äidin tai vaimon) ääntä imitoiden. Mannisen mukaan horkalla ei ole erityisiä ulkoisia piirteitä (Manninen 1922, 146). Eteläkarjalaisessa loitsussa kuvaillaan horkka tappuraiseen takkiin pukeutuneeksi äijäksi, joka kiertää maata muille pahaa toivoen (SKVR XIII 3, 9515). Yhdessä pohjoissavolaisessa tarinassa sanotaan, että yövieraalla on ollut pää parsiin saakka ja iso nenä (vrt. loitsussa horkan nimitys konk.konokka). Olio itse mainitsee, että hän on Räkä, Rähmä ja Kolkko-poika kolmantena (Honko 1959, 154). Luonnottoman pitkäksi kuvaillaan myös ihmishahmoista pirua (Jauhiainen/Simonsuuri E 101) ja muita supranormaaleja olentoja. Sortavalalaisen tarinan mukaan horkka oli ihmistä lyhyempi, ihmisenkaltainen, harmaissa vaatteissa liikkuva olento, joka ilmestyi miehelle naisen ja naiselle miehen hahmoisena. Tässä tarinassa horkka "alkoi tilalla voihkia" ja "kiemuroida", se "paini" ja "vatkasi", joten kyseessä on pikemminkin toiselle mytologiselle sairaudelle, painajaiselle, tyypillinen käyttäytyminen.

Horkka käy vaivaamassa uhria yksin, mutta esimerkiksi maantiellä tai muualla luonnossa se liikkuu muiden horkka-hahmojen tai "rään ja rähmän" seurassa. Tarinoissa horkka tavataan yleensä ilta- tai aamuhämärässä, mutta tauti iskee yleensä päiväsaikaan, aina täsmälleen samana ajankohtana, niin että uhri jo tietää horkan tulon. Horkan öinen ilmestyminen liittyy tarinatyyppiin, jossa esiintyy tietynlainen unihaltija (1) unihuppias (Jauhiainen/Simonsuuri A 811) tai unikakkiainen (ibid. A 821), joka ilmoittaa, että sairaus lähtee vain hevosella kuljettamalla. Horkalle ominaisia ovat hyvin kehittynyt hajuaisti ja kuulo. Venäjällä horkka esitetään sokeana (Honko 1959, 154), mutta Suomesta vastaavaa kuvitelmaa ei löydy, vaikka teksteistä ilmeneekin, ettei se pysty tavoittamaan uhriaan pelkän näköaistin avulla. Uskotaan, että horkka ei pidä siitä, että sille nauretaan ja sitä pilkataan - tämä on ominaista myös muille supranormaaleille olioille. Esimerkiksi pilkattu para, talonbaltija tai piru voi kostaa polttamalla talon tai lopettamalla tavaran kuljettamisen. Horkka ei muiden yliluonnollisten olentojen tavoin myöskään pidä sotkusta ja liasta, mikä antaa uhreille mahdollisuuden piiloutua likaiseen paikkaan, kuten siansontaan. Horkka ei myöskään pysty seuraamaan uhria saunaan, ja se joutuu lähtemään, jos uhri piiloutuu uuniin.

Horkalle ovat ominaisia transformaatiot, joiden avulla se pyrkii uhrin sisälle. Se voi muuttaa itsensä oljen- tai sammalenporoksi ja laskeutua katosta ruuan (maidon, puuron tai kiisselin) päälle. Jos uhri syö sen, hän joutuu horkan vaivaamaksi. Tarinassa mainitut ruuat, kuten puuro ja maito, ovat myös olleet uhrianteja, joita on suotu esimerkiksi paralle (Krohn 1914, 98).

Eläinhahmoiseksi horkka kuvataan vain kahdessa tarinassa. Jälleen voidaan epäillä, että niissä kyseessä on itse asiassa jokin muu sairaus. Savolaisessa tarinassa 


\section{Piret PaAL}

luetellaan, että horkka voi ilmestyä kissana tai härkänä. Toisessa nähdään horkka punaisena kukkona: 'Vitsanurmen Bergmannilla oli punainen kukko kiekunut pihaveräjän päällä keskellä yötä, vaikka kukkoa ei ollu siinä talossa eipä edes naapurissakaan.” (SKS KRA, Kaljunen, Impi KT 72:16, 1938.) Suomessa punainen kukko on punaisen lankakerän ohella tavallisin ruton esiintymismuoto (Hästesko 1910, 131; Honko 1959, 153). Kerran mainitaan, että horkka on yksisilmäinen pukinkaltainen olio, jolla on otsassa iso sarvi:

[..] oli ilmestynyt puoleksi unenhorrossa ja puoleksi valveilla sellainen olento twvan lattijallen, lähellen emännän tilaa. Sillä oli ollut kaksi jalkaa, samanlaista kuin pukilla ja y ksi sarvi, iso kuin pukin sarvi ja yksi iso silmä keskellä otsaa ja kummallakin olkapäällä kuin käsirievut rïppuneet, joka oli sanonut olevansa horkeka. (SKS KRA Kolehmainen, Juho 2, 1938.)

Pasi Klemettisen mukaan yksisilmäisyys on yksi pirulle ominainen demoninen piirre (Klemettinen 1997, 73), mutta vielä yleisemmin tunnettuja ovat Suomessa kertomukset yksisilmäisestä tontusta (Haavio 1941, 281-294).

Virolaisesta tarina-aineistosta voi päätellä, että horkka on myös näkyvä olento (Paal 2004, 52-54), mutta Suomessa vain kuullaan tautidemonien välisiä keskusteluja. Tautien tavallisia keskustelupaikkoja ovat tiet ja tienristeykset:

\section{Vanhaan aikaan uskottiin, että nämä taudit kulkivat usein baamu olentoina yön aikoina paikasta toiseen. Ja nämä haamut olivat usein pubelleet keskenään kulkiessaan. Kerran kuultiin kabden tälläisen haamun seuraava keskustelu talon lähellä tiellä illan hämärässä. Ä̈̈nen kuultiin sanovan nä̈n: "Mite sie määt nyt ensimäisen ubrisi sisälle?" Ja toinen ääni vastasi: "Mie mään butun silmässä," ja samalla kysyi toiselta: "Mites sie määt?" Ja ääni vastasi: "Mie mään maitoläm- mitykesen pinnalle nousussa kuplassa (ilmarakkula). (SKS KRA Hyvärinen, Juho 1335, 1938.)}

Kerran kuullaan taudin suunnitelmista myös, kun tämä on kumppaneidensa kanssa veneessä (SKS KRA Pyykkö, Vilho TK 77:7, 1961). Tarina, jossa horkkaa kuullaan järvellä, poikkeaa yleisestä uskomuksesta, jonka mukaan horkka (samalla tavalla kuin muut tartuntataudit ja vainajaolennot) ei päässyt itsenäisesti veden yli.

Pahantahtoisen naapurin tai tietäjän nostattamasta horkasta on Suomessa tallennettu vain vähän esimerkkejä. Inkeriläisen kertojan mukaan horkalta ei kukaan ollut suojassa: "Velho saattoi lähettää horkan toiseen ihmiseen, monesti viattomaan lapseen. Mutta saattoipa horkka tulla velhoon itseensäkin.” (SKS KRA Savelius, Olga PK 34: 6116, 1938.) Yhdessä tarinassa horkka kutsuu uutta uhria seuraavalla tavalla: "'Kuulehan Tuomas! Henrikki käski miun tulla siun kansas heinälle.' Henrikki oli naapurin talon isäntä ja hänessä oli ollut horkka jo kolme viikkoa.” (SKS KRA Kaljunen, Impi KT 72:16, 1938.) Toisin kuin virolaisessa horkkaperinteessä, suomalaisissa kertomuksissa ei esiinny lappilaisten noitien tekemää horkkaa. Lapin naisten ja miesten esiintyminen etelävirolaisissa horkkatarinoissa on mielenkiintoinen motiivi, jota 
Piret PaAl

Myyttisen hiiden hevosen väri on ollut perinteisesti musta tai vaskenkarvallinen (Siikala 1994, 95). Hevonen esiintyy taudin kuljettajana myös monien Siperian kansojen uskonnossa (Ränk 1981, 75-90). Saamelaiset taas tuntevat Ruto(Rota)-nimisen pahan hengen, jota shamaanirummussa symboloivat (ks. kuva 1.) hevonen ja ratsastaja (Ränk 1981, 89). Juha Pentikäinen kuvaa Ruto-jumaluudelle suoritettua hevosriittiä, jossa hevonen tapettiin ja haudattiin maahan, jotta Ruto sen selässä ratsastaisi kotiinsa (Rotaimo) ja jättäisi kiusaamansa ihmisen rauhaan (Pentikäinen 1995, 242-243). Pasi Klemettisen mukaan myyttinen hevoshahmo symboloi useissa eri uskomusjärjestelmissä supranormaalia siirtymistä tilasta, paikasta tai olomuodosta toiseen (Klemettinen 1997, 82). On myös esitetty, että hevosmotiivi

kuvaa kulkutautien etenemistapaa

(Itkonen 1946, 136).

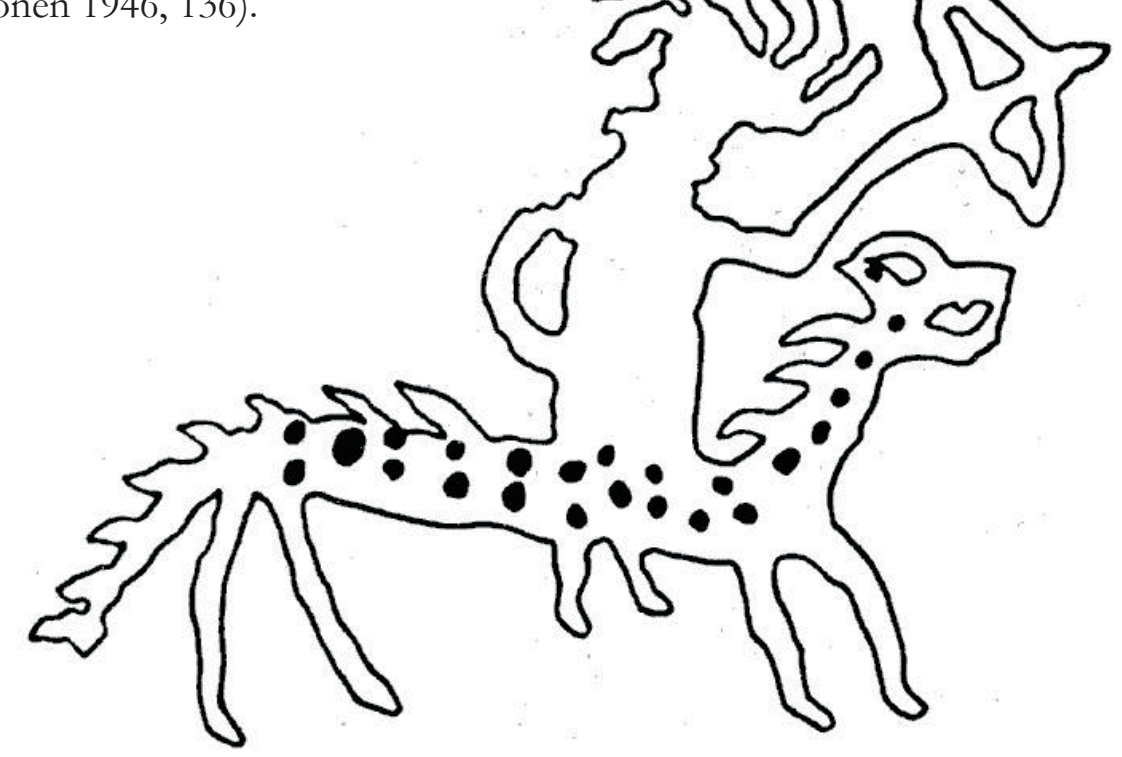

Kuva 1. Ratsastajankuva samaanirummulla. Pelottavannäköiset ratsastaja ja hevonen kuvaavat todennäköisesti sairautta.

Suomalaisesta horkkaperinteestä löytyy motiivi, jossa horkka pyytää kyytiä toiseen taloon, sanoen: "Pääset minusta, kun kyyhiet toisee talloo!" (SKS KRA Partanen, Jorma 6, 1936.) Hevosmies suostuu tarjoukseen ja valjastaa hevosen. Samankaltainen hevosella kuljettamisen motiivi esiintyy myös Pohjois-Suomessa, jossa kirkkaanpunaisiin vaatteisiin pukeutunut mies (tubkarokko) tulee taloon ja pyytää kyytiä (Honko 1959, 154). Kaksi samantyyppistä tekstiä samalta alueelta kertovat, että kyseessä olisi ollut rutto (Heinonen 1955, 9). Ilmeisesti tässäkin tapauksessa on kyseessä kontaminaatio, jossa rutto on saanut tuhkarokon ominaisuudet (vrt. Jauhiainen/Simonsuuri Q 21), koska ihmishahmoinen rutto on tunnettu vain Länsi-Suomessa.

Horkka voi anoa kyytiä myös veden yli. Pohjoissavolaisessa tarinassa kuljettaja kumoaa lastinsa virtaan ja niin vapaudutaan taudeista kokonaan (SKS KRA Räsänen, Lyyli KRK 117: 10, 1935). Vastaava motiivi on tunnettu Viron saariston ja rannikon ruttoperinteessä (Hiiemäe 1997, 61). Sairausolennon sijaan uhrille voi unissa ilmestyä 


\title{
HORKKA JA USKOMUSTARINAT
}

myös unihaltija, joka neuvoo, miten taudista pääsee eroon. Aina ei tarvita hevoskyytiäkään, jotta tauti voisi kulkea paikasta toiseen:

\begin{abstract}
Pekan äidissä oli horkka. Unen hourauksessa "borkkea pyrki", minnekkä se mielummin menisi. Se sano, että viijä hänet kanavamiesten (laokkeuun) eväskonttiin, että bään mänis kanavalle. Äiti kär kontin luona, aokas kontin kielen ja sano: "Mää tuossa nyt". Horkeka lähti pois äidistä, meni kanavalle, jossa monta miestä kääntyi sairaaksi. (SKS KRA Rytkönen, Ahti 3514, 1929.)
\end{abstract}

Sama motiivi löytyy myös suomalaisista ruttotarinoista. Tämän uskomuksen mukaan rutto armahti aina yhden ihmisen päästäkseen itse jatkamaan toiseen kylään (Heinonen 1955,9$)$.

Mielenkiintoinen tarina taudista ja tämän kuljetuksesta löytyy etelä- ja pohjoissavolaisesta horkkaperinteestä. Tässä kaskunkaltaisessa kertomuksessa horkan kuljetus saa jatkonsa käräjillä:

\begin{abstract}
Ennen vanhaan aikaan, kun vilutauti eli horkek raivosi, nïn Kaukolan mies vei bänen väki kuumaan uunïn lautojen päälle, kävi pitkälleen. Se ei maistanut horkasta byvältä. Se rupesi tarinoimaan: "Sie elä piinaa minua tulessa tervassa, vie minua Paksujalan kestikievariin, niin mie lähen teiltä pois tykeänään. Mies löi hevosen valjaisiin ja ajoi Hiitolan puolelle Paksujalan kestikievariin. Meni tupaan. "Mitäs Kaukolan miehelle kuulun?" "Ei mitään erikoista, mie toin teille horkan." Paino hatun [päähän] ja läbti. Jo sinä iltana horkka ravisti emäntää, sitten sanottiin koko perbeen puistelleen. On siintä menty käräjääkin, mutta tuomari on lyönyt leikiksi ja kumonnut koko asian. Ropotti tuvassa kuultu. (SKS KRA Saikkonen, Juho KT 136: 9, 1938.)
\end{abstract}

Samoin käy myös toisessa tarinassa: 'Nost kärräänkäynnin. Tuomarj sano: 'Ku se olj sulla kyyvittävä, mahoit kyyvitä kans toiseen talloon.”" (SKS KRA Savo-Karjalainen Oskunta 36, 1887.) Suomalaisten uskomustarinoiden tutkijan Marjatta Jauhiaisen mukaan tällaiset stereotyyppisistä tarinoista poikkeavat, realistiset ja humoristiset otteet ovat tyypillisiä juuri itäsuomalaiselle kertomusperinteelle (Jauhiainen 1999, 17).

Virossa horkan pois kuljettamista hevosen kyydissä ei tunneta. Hevoskyydillä liikkuminen mainitaan virolaisissa horkkateksteissä kahdesti. Ensimmäisessä tarinassa horkka lähestyy uhria hevosen kyydissä kovasti metelöiden. Tämä muistuttaa pikemminkin metsänhaltijalle tai pirulle ominaista ilmestymistä. Toisessa kuvaillaan horkkanaisia istumassa rattaissa (H I 8, 374/5 (19)). Myös rattaissa matkustelu kuuluu virolaisessa kansanuskossa ensisijaisesti pirun oikeuksiin. Virossa puolestaan tunnetaan laajalti uskomus, jonka mukaan horkka käy ratsastamassa uhrin selässä. Virolaista horkan nimitystä hall käytetään myös harmaasta hevosesta. Etelä-Virosta löytynyt tarinatyyppi kertoo horkasta, joka etsii uhria ratsastaakseen tällä kotiin Lappiin, koska on papujen kylvön aika (H I 7, 662 (2)). Horkan ratsastamiseen uhrillaan viittaavat myös vironkieliset ilmaukset, kuten halli peale tulek eli 'horkan päälle tulo', halli sõit eli 
'horkan kuljetus' tai halli ajamine eli 'horkan ajo'. Horkkakohtauksesta sanotaan Virossa ajab, 'ajaa', tai sõidab halli, 'kuljettaa horkkaa'.

Hevosen selässä ratsastavan tautidemonin esiintyminen naapurikansojen uskomusperinteessä on saanut virolaiset tutkijat ahkerasti etsimään vastaavanlaisia kuvitelmia virolaisesta kansanuskosta. Varhaisimmista tutkimuksista alkaen on keskusteltu juuri horkan mahdollisesta esiintymisestä hevosella ratsastavana tautidemonina. Kirjassa Mytische und Magische Lieder der Ehsten (1854) kuvaillaan horkkaa (Hal, saksaksi der, das Graue) valkoiseksi tai harmaaksi eläimeksi, jonka selässä sairastunut ihminen ratsastaa. Virolaisesta kansankulttuurista kiinnostuneiden estofilien, Neusin ja Kreutzwaldin, mukaan sairastunut henkilö kuvittelee itsensä ratsastajaksi, jota ratsastus sairausolennolla vapisuttaa. Kirjoittajat arvelevat tämän hahmon olevan yhteydessä saksalaisen riton (2), hevosella ratsastavan sairausolennon kanssa, joka kylvää kuumetta (Kreutzwald \& Neus 1854, 92-93). (3) Jakob Hurt kumoaa heidän väitteensä (Hurt 1863, 19-21). Tekstikorpusta silmällä pitäen Hurtin kirjassa Beiträge zur Kenntniss estnischer Sagen und Überlieferungen (Aus dem Kirchspiel Pölwe) esitetyt näytetekstit ovat traditionmukaisia ja uskottavia. Ferdinand Johann Wiedemann käytti varhaisempia kirjoituksia (ks. Mansikka 1945, 10) ja esitti molemmat mahdollisuudet (Wiedemann 1876, 419). Myös Oskar Looritsin virolaista horkkaperinnettä pohtivasta kirjoituksesta (1928) löytyvät molemmat vaihtoehdot eli horkka kuvaillaan sekä ratsastajaksi että ratsuksi. Loorits järkeilee horkan nimityksen etymologiaa jopa seuraavalla tavalla: "Niin voimme todeta, että tautia ei sanota potilaan kasvojen värin takia harmaaksi, vaan siksi, että sairausdemoni kuvitellaan harmaan hevosen selässä ratsastavaksi tai jopa harmaaksi hevoseksi” (Loorits 1998, 255).

Virolaisesta tekstikorpuksesta löytyikin yksi teksti, jossa horkka esiintyi hevoshahmoisena (E 36569/70 (4)), mutta se poikkeaa yleisestä linjasta. Sekä Suomessa että Virossa on hevosta käytetty horkan parannusriitissä: harmaalla tai valkoisella hevosella ratsastettiin taaksepäin. Tämä liittyy parannusnäytelmään, jossa sairautta yritetään siirtää eläimiin. Gustav Ränkin mukaan kysymyksessä on ikivanha kuvitelma siitä, että tauti on jotain substantiaalista tai orgaanis-yksilöllistä, joka voidaan sïrtää eläimiin ja ajaa niiden mukana pois (Ränk 1977-79, 123). Vaikka monet folkloristit ovatkin ahkerasti etsineet kuvitelmaa personifioidusta, hevosen selässä ratsastavasta sairausdemonista, osoittavat sekä suomalaiset että virolaiset aineistot, että kyseinen käsitys on ollut tuntematon.

\section{VANGITTU HORKKA}

Suomalaiset uskomustarinat vangitusta horkasta lähestyvät muodoltaan Baltiassa, Keski- ja Etelä-Euroopassa, Venäjällä ja Skandinaviassa tunnettua satua "Piru säkissä” (AT 330B). Virolaiset kertomukset taas muistuttavat pikemmin satutyyppiä AT 613. Suomesta löytyi yhteensä seitsemän vastaavaa tarinaa (f, $g, h, i, j$ ), joissa kuullaan horkan keskustelevan muiden tautien kanssa tienristeyksessä. Horkka kehuu menevänsä puuron sisään. Tämä on tyypillinen kansainvälisesti tunnettu uskomustarinan 


\title{
HORKKA JA USKOMUSTARINAT
}

motiivi (Jauhiainen/Simonsuuri Q 1-10). Paikallisissa versioissa horkka uhkaa mennä tupakkasäkkiin ja sieltä uhrin sisälle:

\begin{abstract}
Eräät suomalaiset olivat Kesälabdella Villalan kylässä kuulleet kolmen horkan keskustelevan. He eivät näbneet sïnä mitään. Yksi hork.ka ubkasi mennä sïhen, toinen taas sïhen mieheen. Kolmas käkesi mennä Savonlinnassa erääseen mieheen tupakan kautta. Tienhaarassa olevat miehet veivät sanan asianomaisille, että nämä olisivat varuillaan. Sen horkan, joka oli uhannut mennä seppään (Kesälabdella) tämän takoessa hengästyessä, seppä iski alasimeen. Savonlinnan mies kiristi horkan tupakkakukkaroonsa. Kiteelle mennyt horkeka sai myös lopun. Sitten koko horkka hävisi. (SKS KRA Sääski, Sylvi 1017, 1938.)
\end{abstract}

Tarinalle on tyypillistä, että joku kuulee tautien keskustelun ja niin uhrilla on jo valmiina säkki, jonne hän voi horkan vangita. Säkki suljetaan ja ripustetaan tavallisesti muutamaksi viikoksi kuivumaan. Samalla tavalla kuin vastaavanlaisissa kertomuksissa pirusta, vangittua saatetaan työstää kirveen hamaralla ("taputtel sitä kirvespohjallakkii”) (SKS KRA Hyvärinen, Juho 1492, 1938). Eteläkarjalaisessa versiossa käytetään tupakkasäkin sijaan piimäpyttyä, koska uhri syö puuroa pellolla eikä kotona (SKS KRA Pyykkö, Vilho TK 77: 7, 1961). Tämä ilmaisee hyvin, millä tavalla tarinan tapahtumien siirtäminen toiseen kontekstiin muuttaa koko tarinan ilmettä. Harvinaisessa pohjoisvirolaisessa versiossa horkka on mennyt lapasen peukaloon ja haluaa niin vilustaa uhriaan, mutta hänetkin pehmitetään kirvespohjalla (H I 4, 106 (17)). Jonkin ajan kuluttua horkka päästetään kuitenkin lähtemään ja sitten se valittaa huonosta kohtelusta kavereilleen. Suomessa horkka on kolmen kertomuksen mukaan siirretty myös huiviin. Sortavalalainen tarina kertoo, miten mies houkutteli horkan vastaongitun kiisken sisälle:

\begin{abstract}
Kerran ennen kun miehessä oli horkka, ja mies oli järven rannalla ongittamassa, tuli horkka miehen luo ja sanoi: "Täalläkë sinä ongitat?” Nyt mies päätti pettää horkan pä̈̈stäkseen sïtä eroon. Mies oli junri saanut kiisken, bän aukasi kiisken suun ja pyysi hork.kaa menemään kiiskin sisään. Horkka lupautui, mutta sillä ehdolla, ettei mies heitä sitemmin kiiskeeä järveen, jolloin bän, horkkea hukkuisi. Kun hork.ka oli mennyt kiiskin sisään, pubalti mies perään ja työkkeäsi kiiskeeä olevinaan järveen. Ei kuitenkaan työkä̈ssyt. Mies undistiyrityksensä useita kertoja ja työkkäsi kiisken kädessään aivan vedenrajaan asti. Mutta otti aina takaisin. Viimein työkkäsi bän äkkiä kiiskin veteen - veden sisään kädessään ja jätti kiiskin menemään. Sinne meni horkkakin kiisken mukana, ja mies pääsi siitä eroon. (SKS KRA Moilanen, Matti 3640, 1937.)
\end{abstract}

Myös muissa personifioiduista sairauksista kertovissa tarinoissa tunnetaan sairauden vangitsemisen motiivi. Uudellamaalla lankakerän muotoinen rutto suljetaan laatikoon tai säkkiin. Laatikko, jossa rutto on, heitetään jokeen tai hukutetaan järveen. Anjalasta on löytynyt myös tieto koleran säkkiin laittamisesta (Heinonen 1955, 7, 15). Kaikki nämä erilaiset kertomukset taudin vangitsemisesta heijastavat näkemystä, jonka mu- 


\title{
Piret PaAL
}

kaan kulkutaudit voitiin joskus pysäyttää, mutta tietyn ajan kuluttua (aikaa ei määritellä tarkemmin) ne olivat taas liikkeellä.

\section{HorkKa huUtaA HUTUlle}

Uhria nimeltä kutsuvasta horkasta on yhteensä 19 karjalaista (i, h, j) toisintoa. Virolaisessa kontekstissa horkka kutsuu uhriaan, koska se haluaa kyytiä (Paal 2004, 56-47). Suomessa horkan hahmon tavoitteet ovat monimutkaisempia. Pelkän etsimisen lisäksi ('Kati, Kati, tule pois!" tai "Onks Villem tääl?"), horkka voi kutsua uhria pois piilopaikastaan joko emännän tai äidin äänellä, kehottaen tulemaan puurolle:

\begin{abstract}
Kerran ennen kun eräs Liisa niminen nainen piti hork.kaa, meni bän sitä puistatusajaksi kark.unn potaattikuoppaan, ja kuopan ovi suljettiin visusti. Kun horkeka tuli, meni se kuopan ovelle ja buusi: 'Liisa, tule butulle!" Mutta siihen vastasi nainen: "Mitäs sinä oikein pidät peliä kanssani!" Ja silloin oli horkeka kiinni naisessa ja alkoi puistattaa vilulla. Horkan bubuiluun ei olisi naisen pitänyt mitään vastata, ja se olisi mennyt pois. (SKS KRA Moilanen, Matti 4782, 1938.)
\end{abstract}

"Tule hutulle!" on tälle tarinantyypille tunnusomainen piirre. Horkan oveluudesta kertoo sekin, että se voi houkutella uhria piilopaikastaan tilannetta hyväksi käyttäen:

\section{Jauhon ostajia tul monta yhtä aikua, tule antamaan jauboa ostajille! (SKS KRA Hyvärinen, Juho 1492, 1938.) \\ Yllö, tule pois vällei! Nimismies myöp kaik karjas huntokaupal! (SKS KRA Ravantti, Aino TK 86: 12, 1961.)}

Yhdessä tekstissä horkka käyttää edesmenneen vaimon ääntä houkutellessaan miestä pois sianpeuhoista: "Kaiken puhtahan paijan likautat!" (SKS KRA Kähmi, Martta 412, 1938). Juuri emännän tai äidin äänen käyttö on "Tule hutulle!” -tarinatyypille ominainen. Ruoka on tässä tarinatyypissä keskeisessä asemassa, koska uskomuksen mukaan horkka voi transformoida itsensä poroksi ja piiloutua ruoan, erityisesti maitokeiton tai puuron sisälle, jota kautta se pääsee uhria vaivaamaan.

Tautien keskinäisen keskustelun lisäksi suomalaisissa tarinoissa kuvaillaan myös horkan ja hänen uhrinsa keskustelua. Esimerkiksi horkka pahoittelee saunan lauteilla olevalle miehelle, ettei pääse tämän luokse: "En mie sin tule, mie vaan oon tääl, siu vaatteis pääl!' (SKS KRA Heinonen, Miina 4943, 1938) tai uunissa horkasta eroa etsivälle: "Pekka tiälä tuloo helle!" (SKS KRA Hyvärinen, Juho KRK 141: 90, 1935/36). Ortodoksisella hautausmaalla olevaan kappeliin piiloutunutta miestä varoitetaan toisena yönä: "Kolmanneks yöks elä tule enää tänne makuamaa, tiä ei oo eläviin lepopaikka, tiä kuuluu kuolleille!’' (SKS KRA Hyvärinen, Juho KRK 141: 102, 1935/36). Kertojien mukaan horkka voi jopa suuttua ihmiselle, joka on käyttänyt 
tiettyjä maagisia häätökonsteja: "Kukas sinun käski juomaan hevosen maituu, kuka heille kaikki vai neuvoo!' (SKS KRA Hyvärinen, Juho 1353, 1938) tai itsensä ulosteilla voidelleelle miehelle: "Pois mie lähen näi siivottoman miehen luota!" (SKS KRA Hyvärinen, Juho 1458, 1938). Pahanhajuisen tai maagista väkeä sisältävän ruoan ja juomien nauttiminen tai piiloutuminen lantakasaan olivat horkan torjunnassa yleisesti käytettyjä menetelmiä.

Horkka voi joskus myös itse neuvoa, miten siitä päästään eroon: 'Kun sinulla on taskussa se kääntöpääveitsi, ota viila siitä jauhoa, jotka viilajauhot sekoitat aamukahviin ja juot suuhusi. Kun olet viilajauhot juonut, lähden minä pois!" (SKS KRA Moilanen, Matti KRK 146: 703, 1935/36) tai: "Sie elä piinaa minua tulessa tervassa, vie minua Paksujalan kestikievariin, niin mie lähen teiltä pois tykkänään!” (SKS KRA Saikkonen, Juho KT 136: 9, 1938). Tämä värikäs kokoelma erilaisia keskusteluja ilmaisee itäsuomalaiselle horkkaperinteelle tyypillistä ominaisuutta - näkemystä, että horkka pystyi käyttämään erilaisia ääniä keskustellessaan uhrin kanssa. Dominoiva on tutun äänellä huutaminen. Horkan ääni kuullaan samoissa paikoissa, joissa kertomuksien mukaan ilmestyvät myös muut supranormaalit oliot, kuten piru saunassa, kuolleet hautausmaalla tai metsänhaltija metsässä.

\section{SUOMALAISTEN HORKKATARINOIDEN TEEMOJA JA TEEMARAJOJEN YLITYKSIÄ}

Virolaisen ja suomalaisen horkkaperinteen teemoissa voi havaita monia eroja. Virossa horkan synty on yhteydessä Lapin noitiin: noita voi esimerkiksi antaa uhrille lahjan, johon on kätketty tauti (ERA II 160, 331 (41)). Suomessa tunnetaan tarinoita, joissa tauti kertoo nimensä tai pyytää kyytiä toiseen paikkaan. Suuri osa suomalaisista kertomuksista keskittyy myös taudin parantamisen ja siihen liittyvän parannusriitin kuvaamiseen.

Niin Suomessa kuin Virossakin horkalle on tyypillistä, että se voi esiintyä tarinatyypeissä, joissa stereotyyppisesti esiintyvät muut uskomusolennot. Tällaisessa tarinassa horkka voi olla pelkkä komplikaatio, josta yritetään päästä eroon. Suomalaisessa tarinassa, jossa tietäjä puhuttelee pirua - "Ethän sinä tiedä..?” (Jauhiainen/ Simonsuuri D 421) - kysytään pirulta, milloin horkka lähtee. Tässä tarinassa paino on selvästi tietäjän ja pirun kommunikaatiossa, mutta siitä löytyy myös horkkakertomuksille ominainen parannusriitin kuvaus. Marjatta Jauhiaisen mukaan kuolleista, pirusta ja tietäjän toiminnasta kertovat tarinat ovat keskeisiä juuri itäsuomalaisessa kertomustraditiossa (Jauhiainen 1999, 17).

Jauhiainen-Simonsuuren suomalaisten uskomustarinoiden tyyppi- ja motiiviluetteloa käyttäen on mahdollista esittää suomalaisten horkkatarinoiden teemat muiden uskomustarinoiden kanssa rinnakkain seuraavalla tavalla [hakasuluissa horkkaan liittyvät lisäykset]: 


\section{Piret PaAl}

\section{A Enteet ja kohtalo}

811, 821 Unihuppias, unessa ilmaantuva (yleensä) hahmoton olento - neuvoo, varoittaa, ilmaisee tulevia tapahtumia. [Unihuppias (tai horkka itse) neuvoo horkan lähtemisen ajan ja tavan.]

\section{Kuolema, vainajat ja kalma}

491 Kotonakulkija karkotetaan - vainaja käännetään arkussa vatsalleen tai siltä katkaistaan kantasuonet, paluutielle kylvetään pellavansiemeniä, vainajaa ammutaan hopealla, luetaan siunaus, pappi karkottaa. [Horkkatautista parannetaan arkussa. Arkun naulan raapaisusta seuraa ruumiin koi eli syöpä.]

1671 Hautaristin, jonkin kirkkoon tai hautausmaahan kuuluvan esineen ottaminen - aiheuttaa kummittelua, onnettomuutta - hautausmaanväki ilmestyy. [Hautausmaalta mukana otettu esine horkan syynä. Palauttaminen päästää horkasta.]

\section{421 Tietäjät, noidat}

Tietäjä puhuttelee pirua, supranormaalia olentoa - kysyttävä inttäen: 'Ethän sinä tiedä...?" - olento neuvoo sairauden aiheuttajan ja parannuskeinon - selvittää varkauden. [Tietäjä kyselee pirulta: "Ethän sinä tiedä..? ja saa vastaukseksi horkan lähdön ajan.]

\section{E Piru, paholainen}

451 Piru ja hirttäytyjä - piru hirttäytyjän luona neuvomassa ja nuoraa kiristämässä. [Piru ojentaa (parantamisnäytelmässä) itsemurhaa suunnittelevalle tautiselle kestävämmän köyden.]

\section{Q Tautidemonit ja taudit}

1-10 Horkka, vilutauti - liikkuu ihmisten parissa, joskus ihmishahmoisena - horkat keskustelevat siitä, millä tavoin pääsevät ihmisen sisälle: puhuttelevat ihmistä ja jos tämä vastaa, livahtavat ihmisen sisään, tai pääsevät ihmiseen puuron tai maitokeiton mukana - horkkaa petetään panemalla sairaan sijaan vuoteeseen puuhalko - horkasta vapaudutaan piiloutumalla lantakasaan tai uuniin, kyyditsemällä se reellä toiseen taloon, vangitsemalla tupakkakukkaroon [vrt. artikkelissa käsiteltyä] .

11 Rutto - liikkuu punaisena kukkona - lentää, pistää ihmistä - vangitaan rasiaan ja upotetaan iäksi veden pohjaan. [Horkka punaisena kukkona. Horkka puhalletaan kiisken sisälle ja upotetaan järveen.]

21 Kulkutauti, rokko, isorokko, kolera - liikkuu ihmisten parissa, joskus punapukuisen ihmisen hahmossa - herättää yöllä ja vaatii kyytiä - kyyditään hevosella toiseen taloon [Horkka pyytää kyytiä toiseen taloon.]

201 Painajainen, painaja (asthma nocturnum) painaa aikuista ihmistä yöllä unessa - painajainen usein pahansuovan ihmisen, vainajan tai lapsivainajan hahmossa - painajainen karkotetaan heittämällä sitä teräsaseella, virsikirjan avulla tms. keinoilla. [Horkka vaivaa naista tai miestä. Ei saa päästää horkkaa selkään. Karkotetaan riisumalla vaatteet.]

Horkka siirtyy tarinoihin, joissa stereotyyppisesti esiintyy toinen uskomusolento, myös Virossa. Mainio esimerkki on tarinatyyppi, jossa mies ottaa horkan vaimokseen (ERA 
II 54, 28/30 (12)). Tässä yleensä painajaisesta kertovassa tarinassa (vrt. Aa 59, Jauhiainen/Simonsuuri Q 251) morsian kuvataan Lapista kotoisin olevaksi naispuoliseksi horkaksi (ks. lisää aiheesta Paal 2004, 60-63; 65-66). Tämä paljastaa sen, että mikäli tarinan skeema on kertojille hyvin tuttu, kertomuksessa olevia mytologisia hahmoja tärkeämmäksi nousee tarina itse ja sen taitava kertominen.

\section{HORKKATARINOIDEN MAHDOLLISET FUNKTIOT}

Lännestä tulleet tarinamotiivit ovat suomalaisten folkloristien mukaan tyypillisiä pääasiallisesti Länsi-Suomen suullisessa perinteessä (Haavio 1967, 146). Itäsuomalaisissa tarinoissa keskeisiä tarinatoimijoita ovat kuolleet ja piru. Erillisen ryhmänsä muodostavat tarinat, jotka kertovat tietäjän toiminnasta ja keskittyvät parannusriittien ja maagisen toiminnan kuvaamiseen. Itäsuomalaista perinnettä on eniten muokannut se, ettei tarinoiden kertominen ole yleensä ollut ensisijaisesti esiintymistä vaan toiminut osana arkikeskustelua erilaisissa sosiaalisissa tilanteissa (Jauhiainen 1999, 16-18; Sarmela 1994, 156-157). Vaikka suomalainen horkkaperinne keskittyy kahden kansainvälisesti tunnetun tarinatyypin (tautien keskustelu ja uhria nimeltä etsivä horkka) ympärille, nämä tarinat ovat saaneet runsaasti paikallisia piirteitä, joissa paino on arjen tapahtumissa ja käytännön asioissa, kuten esimerkiksi horkasta vapautumisessa.

Unkarilaisen folkloristin Linda Déghin mukaan tarinoiden ymmärtäminen on mahdollista vain kun tulkinnassa otetaan huomioon ihmisten elämäntavat, uskomukset ja kulttuuri-ideologia. Dégh muistuttaa, ettei tarinan funktiona ole pelkästään ihmisten viihdyttäminen vaan tarinan tehtävänä on jakaa ihmisille tietoa ja suojella kulttuurille ominaisilta vaaroilta (Dégh 1972, 73). Funktioanalyysi folkloristiikan metodina edellyttää perinteen tutkimusta kontekstikeskeisenä, koska vain silloin on mahdollista selvittää tarinoiden reaaliaikaisia tarkoituksia ja tavoitteita. Tarinan funktioista voi arkistotekstejä tutkiessa esittää ainoastaan erilaisia tulkintavaihtoehtoja. Horkkakertomukset on arkistoitu ilman minkäänlaisia merkintöjä esitys- tai kulttuurisesta kontekstista. Ajalle tyypillisistä keruumetodeista ja tutkimusmenetelmistä johtuen puuttuvat myös tarinoihin liittyvät kertojien kommentit ja kerääjien huomautukset. Siksi horkkatarinoiden funktiota voidaan lähestyä vain teoreettisesti, käyttäen lähtökohtana tutkijan kognitiivista ymmärrystä kertomusten tavoitteista.

Marjatta Jauhiaisen mukaan uskomustarinoille tyypillinen funktio on kuulijoiden varoittaminen taburikkomuksista (Jauhiainen 1982, 78-79). Horkkatarinoista löytyy joitakin normatiivisia viittauksia, kuten että vieraiden kanssa ei saa puhua, ruuan kanssa ei saa leikkiä ja sopimaton nauraminen voi olla vaarallista. Samankaltaisia viittauksia esiintyy myös muissa uskomustarinoissa, joissa kelvoton käytös voi johtaa supranormaalin olennon ilmestymiseen. Tämä ei kuitenkaan aina päde horkkakertomuksiin. Yleinen mielikuva sairauden aiheuttajasta oli eräänlaisena henkiolentona maata matkusteleva tautidemoni, joka kirjaimellisesti "tuli ihmisen päälle" ilman mitään erityistä syytä. Niinpä horkkakertomuksen yhtenä funktiona on selittää ja kuvata tartuntataudin kulkua kyseiselle kulttuurille ominaisella tavalla. 
Rikkomuksen ja rangaistuksen teemaa norjalaisissa tarinoissa tutkinut Ronald Grambo toteaa, että tarinoissa ilmaistaan kertojien moraalisia käsityksiä maailmasta ja tarinankertojien tarkoituksena on antaa kuulijoille moraalinen oppitunti (Grambo 1970, 253). Taudeista kertovien tarinoiden tehtävä on ensisijaisesti välittää kuulijoille tietoa sairaudesta eli selittää tapahtumien kulkua ja syitä. Kertomusten heijastamien uskomusten mukaan tauti piileksi vieraissa vaeltajissa ja tarttui ihmisiin erityisesti tienristeyksissä, metsien ja peltojen reunoilla sekä veden ääressä - eli sellaisissa paikoissa, missä usein ilmestyvät myös muut supranormaalit uskomusolennot.

Tarinoiden avulla opeteltiin tuntemaan sairauden oireita, mutta myös tapoja, joilla sairaudelta vältytään, sekä konsteja, joiden avulla sairautta torjutaan. Kansanlääkinnälle ominaisia torjuntatapoja esiintyy kaikissa horkkakertomuksissa. Toiset niistä ovat kuitenkin fiktiivisiä eli vain kertomuksille ominaisia, toiset myös todellisessa käytössä olleita. Horkan parannuskeinojen välittäminen tarinoiden avulla on talonpoikaisyhteiskunnalle ominaista tiedonvälitystä. Tarinoiden avulla annetaan varmuus siitä, että supranormaalista taudista on mahdollista vapautua. Kalle Achté ja Taina Schakir kirjoittavat, että tavallisesti sairaudet aiheuttavat stressiä, regressiivistä ajattelua, riippuvuutta, ahdistusta ja masennusta (ks. esim. Achté \& Schakir 1983, 184). Näin ollen kyseessä on myös psykologinen prosessi, jonka avulla osoitetaan, että tuntemattomasta ja vaarallisesta taudista on mahdollista vapautua olemassa olevien tietojen avulla. Sairaudesta kertominen ja sen parannuskeinojen välittäminen antaa ihmisille mahdollisuuden selittää akuuttia ongelmaa ja etsiä tarvittavia ratkaisuja.

Perinteisen genreluokittelun mukaan uskomustarinat kuvaavat kansanomaista uskomusmaailmaa, joten yksi uskomustarinan tärkeimmistä määrittelykriteereistä on ollut, että siihen uskotaan (ks. esim. Honko 1980, 23). Tekstikorpuksesta löytyvien kertomuksien avulla ei ole mahdollista selvittää, uskottiinko horkkatarinoihin vai ei. Tarinan tapahtumiin ja ihmisiin uskominen tai epäusko ei kuitenkaan ole esteenä tarinan kertomiselle. Tarinat olivat luonnollinen osa jokapäiväistä tiedonvälitystä. Kertojalla on käytössään runsaasti vaihtoehtoja suhtautumisensa ilmaisemiseen. Hänen pääasiallinen tehtävänsä on kertomuksen taitava kertominen. Voidaan kuvitella, että sairauden ollessa akuuttina tarinan tapahtumiin uskottiin. Sairaudesta ja parannuskeinoista kertominen antoi ihmisille mahdollisuuden selittää akuuttia ongelmaa ja etsiä tarvittavia ratkaisuja. Myöhemmin, taudin taantuessa, tarinat muuttuivat viihteeksi, kunnes hävisivät suullisesta perinteestä kokonaan.

\section{KERTOMUSPERINTEEN JA TODELLISUUDEN VÄLINEN SUHDE}

Kertomisprosessille ovat ominaisia tietynlaiset valinnat, joista tekstikorpuksesta ei saa tietoa. Kertoessaan tarinaa, jossa horkkaa sairastava henkilö yrittää päästää horkasta eroon teeskentelemällä itsensä hirttänyttä, kertoja saattaa esittää samalla myös motiivin, jossa jonkinlainen supranormaali olento (esim. piru) ojentaa hirttäytyjälle kestävämmän köyden (Jauhiainen/Simonsuuri E451). Uskomusolentojen joustava siirtyminen asiayhteydestä toiseen ilmaisee tärkeätä aspektia, joka täytyy ottaa 


\section{HORKKA JA USKOMUSTARINAT}

huomion kertomuksia analysoidessa: kertomuksissa esiintyvät kuvitelmat eivät aina heijasta traditiolle ominaisia uskomuksia. Kertomisen tavoite kun ei ole todellisuuden kuvaaminen vaan ensisijaisesti tärkeän teeman jakaminen kuulijoiden kanssa tai mahdollisesti kuulijoiden viihdyttäminen.

Sairaudet, joiden alkuperä on tuntematon, ovat panneet alulle supranormaaleihin selityksiin perustuvan kertomustradition. Tarinoiden tehtävänä on kertoa kuulijoille tautien leviämisen syistä, sille ominaisista oireista ja parannuskeinoista. Klassisen käsityksen mukaan tarinoita kerrotaan, koska niiden avulla kuulijoille välittyy tieto, joka tyydyttää kuulijoiden mielenkiinnon. Tarinan avulla ilmaistaan ja selostetaan maailman tapahtumia, jotka voivat tulla kenen tahansa osaksi (Dégh 1995, 82). Sairauden käsitteleminen supranormaalina heijastaa talonpoikaisyhteiskunnan käytäntöä selittää maailmaa kertomuksien avulla.

Eri kulttuureiden sairauskäsityksiä ja -selityksiä tutkineen Ervin Heintz Ackerknechtin teorian mukaan horkka voidaan luokitella sellaisten tartuntatautien ryhmään, joilla on luonnollinen alkuperä. Ackerknecht käsittelee infektioita vaarallisen elävän olennon tunkeutumisena uhrin sisälle (Ackerknecht 1982, 8-21). Suomalaisissa horkkatarinoissa sairauden syy on tautidemonin "päälle tulo", harvemmin ilkeän naapurin tai tietäjän pahantahtoinen toiminta. Suomalaisissa uskomustarinoissa esiintyvä horkka on miespuolinen henkiolento, jolla ei ole merkittäviä ulkoisia piirteitä. Kuten monella muulla demonisella olennolla, horkalla on rajoitettu näköaisti, mutta se kuulee ja haistaa paremmin kuin ihmiset. Tämä on kertomusperinteelle ominainen tapa kuvailla tautien leviämistä ja etiologiaa.

Klassisen genreluokittelun mukaan tarinoihin uskottiin ja sadut olivat fiktiota. Tämän käsityksen mukaan uskomustarinoille on myös tyypillistä, että ne ovat tiettyyn paikkaan sijoitettuja ja sidoksissa tiettyihin ihmisiin. Tekstikorpuksesta löytyy kuitenkin myös toisenlaisia horkkakertomuksia, jotka poikkeavat tyypillisistä uskomustarinoista. Pikemminkin satuja muistuttavissa kertomuksissa ei määritellä tapahtumapaikkaa eikä -aikaa ja niissä keskitytään roolien välisten oppositioiden kuvaamiseen. Saksalainen Lutz Röhrich on kirjoittanut tutkimuksen satujen ja todellisuuden suhteesta. Hänen työssään tarinat ja sadut on asetettu vastakkain, vaikka Röhrichin mukaan myös sadut heijastavat todellisuudessa olemassa ollutta ajattelutapaa ja käyttäytymistä ja myös sadut perustuvat olemassa olleisiin uskomuksiin (Röhrich 1991, 73). Röhrichin tutkimuksessa on runsaasti esimerkkejä eri kertomustraditioissa esiintyvistä yksinkertaisista saduista. Hän olettaa, että mitä yksinkertaisempi satu on, sitä lähempänä se on todellisuudessa olemassa ollutta kansanuskoa (Röhrich 1991,155). Röhrichin kirjasta löytyvien näytetekstien perusteella voi sanoa, että nämä niin sanotut yksinkertaiset sadut muistuttavat paljolti tekstikorpuksesta löytyneitä horkkakertomuksia.

Miksi näin on tapahtunut? Voidaan olettaa, että koska sairaus on taantunut, myös tarinoiden aktuaalisuus on kadonnut. Tämä taas on vaikuttanut tarinoiden kertomiseen. Kertomuksista löytynyt informaatio on tullut sekundaariseksi, ja tärkeään asemaan on noussut roolien välisten oppositioiden välittäminen. Samalla tavalla kirjoittaa myös Röhrich: "Jos uskomisen aika on ohi, kertomus pelastaa itsensä muuttumalla viihteeksi." Tämä osoittaa, että horkkakertomuksissa löytyvät saduille ominaiset vastakkainasettelut ja fiktiiviset roolihahmot ovat perinteen muuttumisen 


\section{Piret PaAl}

prosessin heijastuksia. Tietoa välittävä tarina ihmisiä vaivaavasta taudista on muuttunut ja tiedonvälityksestä on tullut viihdettä.

\section{VIITTEET}

1. Krohn kirjoittaa, että unikakkias eli unikekko on unihaltija eli ihmisen oma haltija (Krohn 1914: 168).

2. Saksankielinen sana ritten tarkoittaa kuumetta. Rito (ride) elikkä ratsastaja on ratsastava sairausolento (ks. Loorits 1998, 246).

3. J. V. Mansikan mukaan Neus ja Kreutzwald saattoivat muunnella alkuperäisiä tekstejä (Mansikka 1945, 8).

\section{LÄHTEET}

\section{Arkistot}

Suomalaisen Kirjallisuuden Seuran Kansanrunousarkisto (SKS KRA)

— Kangasniemi (f), SKS KRA Kuitunen, Oskar 1095 a, 1927.

- Kangaslampi (f), m SKS KRA Sääski, Sylvi 1017, 1938.

— Lauritsala (f/g), n SKS KRA, Kaljunen, Impi KT 72:16, 1938.

- Maaninka (g), m SKS KRA Rytkönen, Ahti 3514, 1929.

— Kurkijoki (h), n SKS KRA Heinonen, Miina 4943, 1938.

— Muolaa, Taaperniemi (h), m SKS KRA Pyyhkö, Vilho TK 77: 7, 1961.

- Sortavala (i), m SKS KRA Hyvärinen, Juho KRK 141: 90, 1935/36.

- Sortavala (i), m SKS KRA Hyvärinen, Juho KRK 141: 102, 1935/36.

- Sortavala (i), m SKS KRA Moilanen, Matti KRK 146: 703, 1935/36.

- Sortavala (i), m SKS KRA Moilanen, Matti 2635, 1937.

- Sortavala (i), m SKS KRA Moilanen, Matti 3640, 1937.

- Sortavala (i), m SKS KRA Hyvärinen, Juho 1335, 1938.

- Sortavala (i), n SKS KRA Hyvärinen, Juho 1458, 1938.

- Sortavala (i), m SKS KRA Hyvärinen, Juho 1492, 1938.

- Sortavala (i), m SKS KRA Moilanen, Matti 4782, 1938.

- Sortavala (i), n SKS KRA Hyvärinen, Juho 1353, 1938.

- Sortavala (i), m SKS KRA Saikkonen, Juho KT 136: 9, 1938.

— Valkjärvi (i), n SKS KRA Ravatti, Aino TK 86: 12, 1961.

— Kitee (j), m/n SKS KRA Vauhkonen, P. VK 107: 32, 1921.

- Nurmes (j), m SKS KRA Partanen, Jorma 6, 1936.

— Juuka (j), n SKS KRA Kolehmainen, Juho 2, 1938.

- Pielisjärvi (j), n SKS KRA Savelius, Olga PK 34: 6116, 1938.

— Siilinjärvi (g), n SKS KRA Räsänen, Lyyli KRK 117:10, 1935. 


\section{HORKKA JA USKOMUSTARINAT}

Eesti Rahvaluule Arhiiv (ERA)

— E 24311/12 (12) < Võnnu khk - P. Rootslane < M. Kerge (1896).

— E 36569/70 (4) < Tarvastu khk., Vooru - J. Kala < L. Üprus, 73 a (1898).

- H I 4, 106 (17) < Jõelähtme khk, Hülga k - F. Matson (1878).

- H I 7, 662 (2) < Kanepi khk, Krootuse v - G. Loodus (1895).

- H I 8, 374/5 (19) < Vastseliina khk ja v, Joora k - J. Sandra < A. Glaser, 65 a (1896).

— ERA II 2, $641<$ Hargla khk, Mõniste v - H. Tampere < M. Eichenbaum, 77 a (1928).

— ERA II 54, 28/30 (12) < Tartu-Maarja khk, Kavastu v - R. Viidalepp < K. Jürjenson (1932).

— ERA II 160, 331 (41) < Vastseliina khk - I. Daniel < M. Toom (1937).

\section{Painamattomat lähteet}

HEINONEN, TUULIKKI 1955: Ruton kulku. Tutkielma suomalaisen ja vertailevan kansanrunoudentutkimuksen seminaarikokoukseen. Helsinki: Helsingin yliopisto. WIEDEMANN, F. J. 1876: Aus dem Inneren und Äusseren Leben der Ehsten. Commissionäre der Kaiserlichen Akademie de Wissenschaften. St. Petersburg.

\section{Kirjallisuus}

AARNE, ANTTI 1918: Estnische Märchen und Sagenvarianten: verzeichnis zu den Hurt'schen Handschriftsammlungen gebörenden Aufzeichnungen mit der Unterstützung der Finnisch-ugrischen Gesellschaft ausgearbeitet. FF Communications 25. Helsinki : Suomalainen Tiedeakatemia

ACKERKNECHT, ERVIN HEINTZ 1982: A Short History of Medicine. Baltimore: John Hopkins University Press.

ACTHÉ, KALLE \& SCHAKIR, TAINA 1983: Parantaminen ja hoitosuhde. - Laaksonen, Pekka \& Piela, Ulla (toim.), Kansa parantaa. Kalevalaseuran vuosikirja 63. Helsinki: Suomalaisen Kirjallisuuden Seura.

DÉGH, LINDA 1972: Oral Folklore. - Dorson, Richard M. (ed.), Folklore and Folklife. An Introduction. Chicago: The University of Chicago Press.

- 1995: Narratives in Society: A Performer Centered Study of Narration. FF Communications 225. Helsinki: Academia Scientiarum Fennica.

DUNDES, ALAN 2002: Kes on rahvas? - Valk, Ülo \& Lepp, Evelin (toim.) Valik esseid folkloristikast. Tartu: Tartu Ülikool, Varrak.

GANANDER, CHRISTFRID 1995: Mythologia Fennica. [Pentikäinen, Juha (toim.).] [Klaukkala]: Recallmed. [1789]

GRAMBO, RONALD 1970: Guilt and Punishment in Norwegian Legends. - Ranke, Kurt (Hrsg.). Fabula, Journal of Folktale studies 11: 253-270. 


\section{Piret PaAL}

HAAVIO, MARTTTI 1942: Sumalaiset kodinhaltiat. Helsinki: WSOY.

- 1967: Kansankertomukset. - Vuorela, Toivo (toim.). Perinnetietoa. Tietolipas 52. Helsinki: Suomalaisen Kirjallisuuden Seura

HAKO, MAT'TI 2000: Kansanomainen lääkintätietous. Suomalaisen Kirjallisuuden Seuran Toimituksia 229. Helsinki: Suomalaisen Kirjallisuuden Seura. [1975]

HIIEMÄE, REET 1997: Eesti katkupärimus. Monumenta Estoniae Antiquae II. Eesti muistendid. Mütoloogilised haigused I. Tartu: EKI Folkloristika osakond, EKM Eesti Rahvaluule Arhiiv.

HONKO, LAURI 1959: Krankheitsprojektile. Untersuchung über eine urtümliche Krankheitserklärung. FF Communications 178. Helsinki: Academia Scientiarum Fennica.

- 1980: Kertomusperinteen tutkimustavat ja niiden tulevaisuus. - Pekka Laaksonen (toim.), Kertojat ja kuulijat. Kalevalaseuran vuosikirja 60. Helsinki: Suomalaisen Kirjallisuuden Seura.

HURT, JAKOB 1863: Beiträge zur Kenntniss estnischer Sagen und Überlieferungen (Aus dem Kirchspiel Pölwe). Dorpat: E. J. Karow, Universitäts-Buchhändler.

HÄSTESKO, F. A. 1910: Länsisuomalaiset tautien loitsut. Helsinki: Suomalaisen Kirjallisuuden Seuran Kirjapainon Osakeyhtiö.

ISSAKAINEN, TOUKO 2006: Vainajien lapset. Taikaesineet ajassa. - Mäkikalli, Maija \& Lahtinen, Anu (toim.), Materiaalisen kulttuurin historiaa. Ennen ja nyt - bistorian tietosanomat 5(2, teemanumero) [online].< http://www.ennenjanyt.net/2006_2/issakainen.pdf $>$ [19.3.2006.]

ITKONEN, ERKKI 1946: Lappalaisten esihistoriaa valaisevia sanoja. - Virittäjä 49: 401.

JAUHIAINEN, MARJATTA 1983: Uskomustarinat. - Järvinen, Irma-Riitta \& Knuuttila, Seppo (toim.), Kertomusperinne. Kirjoituksia proosaperinteen lajeista ja tutkimuksesta. Tietolipas 90. Helsinki: Suomalaisen Kirjallisuuden Seura.

- 1999: Suomalaiset uskomustarinat. Tyypit ja Motiivit. [Tarkistettu ja laajennettu laitos teoksesta Simonsuuri, Lauri1961: Typen- und Motivverzeichnis der finnischen mythischen Sagen.] Suomalaisen Kirjallisuuden Seuran Toimituksia 731. Helsinki: Suomalaisen Kirjallisuuden Seura.

KAIPAINEN, PETRI 2005: Malaria on edelleen yleinen [online]. < http://www.tohtori. fi/?page $=6771267 \&$ id $=0936718>$ [7.12.2006.]

KALLIOINEN, MIKA 2005: Rutto \& rukous : tartuntataudit esiteollisen ajan Suomessa. Jyväskylä: Atena.

KJÆRGAARD, THORKILD 2000: Disease and environment. - Effersøe, Dorte \& Launsø, Laila (eds.), Disease, Knowledge, and Society. Frederiksberg: Samfundslitteratur. KLEMETTINEN, PASI 1997: Mellastavat pirut. Tutkimus kansanomaisista pabolais- ja noituuskäsityksistä Karjalan kannaksen ja Laatokan Karjalan tarinaperinteessä. Suomalaisen Kirjallisuuden Seuran Toimituksia 687. Helsinki: Suomalaisen Kirjallisuuden Seura. KREUTZWALD, F. R. \& NEUS H. 1854: Mytische und Magische Lieder der Ehsten. St. Petersburg: Buchdruckerei der Kaiserlichen Akademie de Wissenschaften.

KROHN, KAARLE 1914: Suomalaisten runojen uskonto. Porvoo/Helsinki: WSOY, Suomalaisen Kirjallisuuden Seura. 


\section{HORKKA JA USKOMUSTARINAT}

LENCQVIST, CHRISTIAN ERICI 1982: Vanhojen suomalaisten teoreettisesta ja käytännöllisestä taikauskosta. - Kajanto, Iiro (toim.), Henrik Gabriel Porthan. Valitut teokset. Suomalaisen Kirjallisuuden Seuran Toimituksia 373. Helsinki: Suomalaisen Kirjallisuuden Seura. [1782]

LOORITS, OSKAR 1998: Liivi rahva usund I-III. Tartu: EKI rahvausundi töörühm ja AS Võru Täht. [1926-1928]

LÖNNROT, ELIAS 1984: Suomalaisten maagisista parannuskeinoista. - Laaksonen, Pekka (toim.) Lönnrotin aika. Kalevalaseuran vuosikirja 64. Helsinki. [1832]

MANNINEN, ILMARI 1922: Die Dämonistischen Krankheiten im Finnischen Volksglauben. Vergleichende Volksmedizinische Untersuchung. FF Communications 45. Helsinki: Academia Scientiarum Fennica.

MANSIKKA, V. J. 1945: Zur Estnischen Volksheilkunde. - Hämäläinen, A. \& Rantasalo, A. V. \& Mansikka, V. J. \& Salminen, V. (Hrsg.), Des Vereins für Finnische Volkskunde III(1-2).

NAAKKA-KORHONEN, MERVI 1997: Vaivasta taudiksi. Lapamatoon liittyvä kansanparannus. Erityisesti pobjoskarjalaisen aineston valossa. Suomalaisen Kirjallisuuden Seuran Toimituksia 666. Helsinki: Suomalaisen Kirjallisuuden Seura.

PAAL, PIRET 2002: Ague in Estonian Folk Medicine. - Arpo, Robert \& Laitinen, Katja \& Laurén, Kirsi \& Vuorinen Pihla (eds.), Beyond Texts. Nord Nytt (85): 97-112.

- 2004: Eesti ja Soome-Karjala halltõvepärimus. Arbiivitekstidel põbinev analüis [online]. Magistritöö. Tartu: Tartu Ülikooli eesti, võrdleva rahvaluule õppetool. <http:/ www. utlib.ee/ekollekt/diss/mag/2004/b16954026/paal.pdf > [19.3.2007]

— 2006: Halltõvega seotud tõrjevõtted ja nende liigitamine. - Mäetagused 34: 111-134. [Myös verkossa < http://www.folklore.ee/tagused/nr34/hall.pdf >] [19.3.2007.] PENTIKÄINEN, JUHA 1995: Saamelaiset - pohjoisen kansan mytologia. Suomalaisen Kirjallisuuden Seuran Toimituksia 596. Helsinki: Suomalaisen Kirjallisuuden Seura. PESONEN, NIILO 1990: Piirilääkärinä Suomessa 1800-luvulla. Porvoo: WSOY.

RÄNK, GUSTAV 1977-1979: Hiiehobune. Särtryck ur Eesti Teadusliku Seltsi Rootsis Aastaraamat VIII. Stockholm, 119-140.

-1981: Der mystische Ruto in der samischen Mythologie. Eine religionsethnologische Untersuchung. Acta Universitatis Stockholmiensis. Stockholm: Almqvist \& Wiksell International.

RÖHRICH, LUTZ 1991: Folktales and Reality. Bloomington: Indiana University Press. [1979]

SARMELA, MATTI 1994: Suomen perinneatlas. Suomen kansankulttuurin kartasto 2. Suomalaisen Kirjallisuuden Seuran Toimituksia 587. Helsinki: Suomalaisen Kirjallisuuden Seura.

SENIOR SCRIBE PUBLICATIONS 2003: Malaria, its history, and the mosquitoes that cause malarial infections [online]. < http://www.wordphiles.info/image-wordunit1/word-image5.html $>$ [12.4.2004.]

SIIKALA, ANNA-LEENA 1994: Suomalainen šamanismi. Mielikuvien historiaa. Suomalaisen Kirjallisuuden Seuran Toimituksia 565. Helsinki: Suomalaisen Kirjallisuuden Seura. [1992]

SIMONSUURI, LAURI 1999: Myytillisiä tarinoita. Suomalaisen Kirjallisuuden Seuran Toimituksia 229. Jyväskylä: Gummerus Kirjapaino Oy. [1947] 


\section{Piret PaAL}

SUOMEN KANSAN VANHAT RUNOT = SKVR XIII, 3 Etelä-Karjala (9515)

VARONEN, MATTTI 1898: Vainajainpalvelus muinaisilla suomalaisilla. Helsinki: Suomalaisen Kirjallisuuden Seuran Kirjapainon Osakeyhtiö.

VUORINEN, HEIKKI S. 2002: Tauti(n)en historia. Tampere: Vastapaino.

- 2006: Tautinen Suomi 1857-1865. Tampere: Tampere University Press.

WYLER, DAVID J. 1990: Plasmodium Species (Malaria). - Mandell, Gerald \& Douglas, Gordon Jr. \& Bennett, John E. (eds.), Principles and Practice of Infectious Diseases.

New York: Churchill Livingstone.

FM Piret Paal on folkloristiikan jatko-opiskelija Helsingin yliopistossa. 